\title{
VARIABILITÉ À LONG TERME DES PEUPLEMENTS DE POISSONS : RÉSULTATS PROVENANT DE RIVIĖRES FRANÇAISES ET OUEST AFRICAINES.
}

\author{
B. HUGUENY (1), H. PERSAT (1), J.L. BAGLINIÈRE (2), P. BOËT (3), G. CARREL (4),
} J.M. OLIVIER (1), D. PAUGY (6), D. PONT (5), K. TRAORE (7)

(1) Ecologie des eaux douces et des grands fleuves, Université Claude Bernard, 43 Bd du 11 Novembre 1918, 69622 Villeurbanne Cedex, France.

(2) INRA, 65 rue de Saint Brieuc, 35042 Rennes Cedex, France.

(3) CEMAGREF, Division Qualité des Eaux, 14 avenue de Saint-Mandé, 75012 Paris, France.

(4) CEMAGREF, Division Hydrobiologie, BP 31, Le Tholonet, 13612 Aix-en-Provence Cedex 1, France.

(5) Laboratoire d'Ecologie des Systèmes Fluviaux, 1 rue de Parmentier, 13200 Arles, France.

(6) ORSTOM, DEC, 213 rue La Fayette, 75480 Paris Cedex 10, France.

(7) IDESSA, Département Piscicole, B.P. 633, Bouaké, Côte d'Ivoire.

\section{RÉSUMÉ}

La variabilité à long terme de 18 peuplements de poissons a été étudiée dans des rivières françaises et ouest africaines. Les principaux résultats sont les suivants :

(1) Le coefficient de variation (CV) de la richesse spécifique, le CV de l'abondance totale et le $\mathrm{CV}$ moyen des espèces constitutives du peuplement augmentent avec la durée de l'étude.

(2) Selon la classification proposée par GROSSMAN et al. (1990) basée sur le CV moyen de l'abondance des espèces, tous les peuplements étudiés rentrent dans la catégorie des peuplements à fortes fluctuations interannuelles. Cependant certaines populations (les salmonidés en Bretagne par exemple) présentent une faible variabilité de leur densité.

(3) Dans le Rhône, les peuplements dont les populations manifestent une grande variabilité interannuelle sont ceux présentant le plus grand taux de renouvellement en espèces. Ce résultat est en accord avec l'hypothèse de HORWITZ (1978, "extermination hypothesis").

Mots-clés : peuplement, extinction locale, turnover en espèces, long terme, variabilité interannuelle.

\section{LONG-TERM VARIABILITY IN RIVERINE FISH ASSEMBLAGES : RESULTS FROM FRENCH AND WEST AFRICAN RIVERS.}

\section{SUMMARY}

Long-term variability of some community parameters was studied in 18 riverine fish assemblages located in France and West Africa. Salient results are :

(1) Coefficient of variation (CV) of species richness, $\mathrm{CV}$ of total abundance and average $\mathrm{CV}$ of population abundance for assemblage members increased with study time span.

(2) Within GROSSMAN et al. classification scheme (1990), which is based on the average $\mathrm{CV}$ of population abundance, all of the assemblages studied show high 
fluctuations through time. However, some individual populations (such as salmonids in Brittany streams) displayed low density variability through time.

(3) In the river Rhône, assemblages in which populations display high year-to-year changes in abundance are those having a high species turnover. This result supports the "extermination hypothesis" (HORWITZ, 1978).

Key-words : community, local extinction hypothesis, species turnover, long-term, interannual variability.

\section{INTRODUCTION}

SCHOENER (1987) recognized seven axes of controversy in community ecology : unpatterned vs patterned, random vs non-random, physical vs biological, interactive vs non-interactive, density independent vs density dependent, non equilibrial vs equilibrial and stochastic vs deterministic. Some of these axes are overlapping and several are prominent in freshwater fish community studies. For instance, after analysing data from a survey of a stream fish community over a 16 years period, GROSSMAN et al. (1982) concluded to the existence of stochastic stream fish assemblages in which species abundance rankings do not remain constant from year to year despite temporally stable habitat structure. This conclusion has been challenged on many grounds (see references in GROSSMAN et al. [1990]) and most of the axes listed above have been involved in the debate.

These controversies have motivated similar studies on freshwater fish assemblages, reviewed by GROSSMAN et al. (1990). However, all such studies have been located in North America. To give a broader overview of the topic we analysed data from long term studies conducted on riverine fish communities located in Europe and Africa. Using these data we tested the following hypotheses.

Hypothesis 1 - There is a positive relationship between indices of interannual community variability and study time span. At the population level, more time means more variation (PIMM, 1991), and the same should be true for community parameters.

Hypothesis 2 - There is a negative relationship between species richness and mean population variability of community members. As indicated by theoretical works and field studies, population persistence of a population is inversely related to variability (PIMM, 1991), so that habitats in which populations display high temporal variability should be subject to high extinction rates that reduce species richness and increase species turnover. Following HORWITZ (1978) we call this hypothesis the "extermination hypothesis".

\section{METHODS}

We assembled data from unpublished long term studies of riverine fish communities at 18 localities all located in large rivers (table I) : three located in the river Seine (France), 11 located in the river Rhône (France), and four in the rivers Bandama, Sassandra and Comoe in Ivory Coast (west Africa). To be included, a study had to encompass at least five years of data. This is the minimum time span considered in similar studies (GROSSMAN et al., 1990). All these localities are located in the main river channel (river width $>30 \mathrm{~m}$, depth $>1 \mathrm{~m}$ ) except localities 12 and 14 which are side arms. River segments sampled ranged from 500 to about $2000 \mathrm{~m}$, but for most localities exact length is not available. Most of the French localities sampled are highly modified by man, especially in the river Rhône (FRUGET, 1992). These modifications affect habitat structure (channelization) and river flow (upstream dam, by-passed sections). Communities were sampled each year, at the same period (spring for French rivers and winter for African rivers) to cancel out seasonal variation and to reduce the catch of young-of-the-year. In French rivers fish were sampled by electrofishing according to two procedures. In the first (continuous sampling, table I), a sample is constituted of the fish caught during a constant time $(20 \mathrm{~min})$ of uninterrupted electrofishing within the locality. In the second procedure (point sampling, table 1), the locality is sampled at constant number of points (25, PERSAT \& COPP (1990)). In west Africa, experimental fishing was carried out using sets of gill nets 25 meters long and two meters deep with various mesh sizes $(15,20,25,30$, and $40 \mathrm{~mm})$ during two consecutive 


\section{Tableau I : Caractéristiques des localités étudiées.}

Table I : Characteristics of the localities studied.

\begin{tabular}{rlllll}
\hline Code & \multicolumn{1}{c}{ River } & $\begin{array}{c}\text { Distance } \\
\text { from source }\end{array}$ & River flow & River bed & Sampling \\
& & & & \\
& & & & \\
1 & Comoe (Ivory Coast) & ca 250 & natural & large pool & gill nets \\
2 & Comoe (Ivory Coast) & ca 450 & natural & large pool & gill nets \\
3 & Bandama (Ivory Coast) & ca 250 & natural & large pool & gill nets \\
4 & Sassandra (Ivory Coast) & ca 300 & natural & large pool & gill nets \\
5 & Rhône (France) & ca 550 & semi natural & channelized & electrofishing (point sampling) \\
6 & Rhône (France) & ca 550 & semi natural & reservoir & electrofishing (point sampling) \\
7 & Rhône (France) & ca 550 & semi natural & reservoir & electrofishing (point sampling) \\
8 & Rhône (France) & ca 550 & regulated & natural & electrofishing (point sampling) \\
9 & Rhône (France) & ca 650 & semi natural & reservoir & electrofishing (continuous) \\
10 & Rhône (France) & ca 650 & regulated & channelized & electrofishing (continuous) \\
11 & Rhône (France) & ca 650 & regulated & channelized & electrofishing (continuous) \\
12 & Rhône (France) & ca 450 & semi natural & natural (side arm) & electrofishing (point sampling) \\
13 & Rhône (France) & ca 450 & semi natural & natural & electrofishing (point sampling) \\
14 & Rhône (France) & ca 450 & semi natural & natural (side arm) & electrofishing (point sampling) \\
15 & Rhône (France) & ca 450 & semi natural & natural & electrofishing (point sampling) \\
16 & Seine (France) & ca 250 & natural & natural & electrofishing (continuous) \\
17 & Seine (France) & ca 250 & regulated & natural & electrofishing (continuous) \\
18 & Seine (France) & ca 250 & regulated & channelized & electrofishing (continuous) \\
\hline & & & & &
\end{tabular}

nights (LÉVÊQUE et al., 1988). Results are expressed as catch per unit effort, which is the number of fish caught in $100 \mathrm{~m}^{2}$ of net per day. These procedures do not provide true estimates of fish density but, rather, indices of abundance which are probably subject to some unknown sampling error. However, for convenience, these indices will be called abundance from now on. We have reason to believe that observed long term changes in our time series are more than random noise. For instance synchronous changes in species abundance were observed between localities 6 and 7 (sampled independently with electrofishing) and between localities 1 and 2 (sampled independently using gill nets). These results are unexpected if we assume that sampling error is the major component of year-to-year changes observed in our data.

For each data set we computed the mean value for the coefficient of variation of population abundance for assemblage members (MCV). Only species present in at least half of the surveyed years were included. The rationale for this index of variation was presented by GROSSMAN et al. (1990). Coefficients of variation of total abundance (CVA) and species richness (CVS) also were computed.

To test if MCV, CVA and CVS increase with the study time span, we computed these indices for the first five years of each time series (reduced values) to compare with those computed from complete time series (complete values). Complete values are expected to be higher than the reduced values if the study time span has a positive effect on community variability through time (Hypothesis I). For each of the three variables studied we computed the number of localities in which complete values are higher than reduced values. Under $\mathrm{Ho}$, we expect that this number would represent fifty percent of the localities and more than fifty percent under $\mathrm{H} 1$. As there are 14 localities for which more than five years of data are available (table II), this expected number is 7 . A paired signed rank test was used to assess the statistical significance of the result.

Communities analysed are located in different rivers and in different habitats. For this reason we did not expect species richness to be directly comparable among localities. To 
Tableau II : Caractéristiques des peuplements étudiés. Les localités sont numérotées comme dans le tableau $\mathrm{I}$.

Table II : Characteristics of the fish assemblages studied. Localities are numbered as in table I.

\begin{tabular}{|c|c|c|c|c|c|c|c|c|c|c|c|}
\hline \multirow[t]{2}{*}{ Code } & \multirow{2}{*}{$\begin{array}{l}\text { Maximum } \\
\text { time } \\
\text { span } \\
\text { (yrs) }\end{array}$} & \multirow{2}{*}{$\begin{array}{c}\text { Total } \\
\text { number } \\
\text { of } \\
\text { species }\end{array}$} & \multicolumn{3}{|c|}{$\begin{array}{c}\text { Mean CV of } \\
\text { populations abundance }\end{array}$} & \multicolumn{2}{|c|}{$\begin{array}{c}\mathrm{CV} \text { of } \\
\text { species richness }\end{array}$} & \multicolumn{2}{|c|}{$\begin{array}{c}C V \text { of } \\
\text { total abundance }\end{array}$} & \multicolumn{2}{|c|}{$\begin{array}{c}\text { Relative species } \\
\text { richness }\end{array}$} \\
\hline & & & 5 yrs & $10 \mathrm{yrs}$ & all yrs & 5 yrs & all yrs & 5 yis & all yrs & 5 yrs & $10 \mathrm{yrs}$ \\
\hline 1 & 16 & 39 & 91.1 & 115.7 & 143.3 & 12.8 & 26.2 & 38.8 & 72.9 & 0.61 & 0.52 \\
\hline 2 & 17 & 40 & 91.0 & 111.1 & 130.3 & 12.1 & 21.6 & 42.7 & 58.5 & 0.66 & 0.55 \\
\hline 3 & 17 & 38 & 109.2 & 112.0 & 128.0 & 25.3 & 38.2 & 55.4 & 70.4 & 0.55 & 0.32 \\
\hline 4 & 13 & 34 & 86.8 & 143.2 & 154.5 & 14.3 & 19.6 & 38.9 & 158.8 & 0.61 & 0.50 \\
\hline 5 & 10 & 20 & 84.0 & 92.8 & 92.8 & 14.4 & 20.6 & 48.7 & 62.5 & 0.70 & 0.55 \\
\hline 6 & 10 & 17 & 74.0 & 84.3 & 84.3 & 19.6 & 25.0 & 45.8 & 66.0 & 0.65 & 0.54 \\
\hline 7 & 10 & 20 & 74.9 & 102.3 & 102.3 & 15.8 & 22.6 & 47.1 & 68.9 & 0.59 & 0.50 \\
\hline 8 & 10 & 20 & 87.4 & 89.8 & 89.8 & 14.7 & 17.7 & 37.0 & 70.2 & 0.67 & 0.56 \\
\hline 9 & 11 & 25 & 114.0 & 112.7 & 112.1 & 34.6 & 24.7 & 45.7 & 33.4 & 0.55 & 0.48 \\
\hline 10 & 11 & 17 & 104.7 & 108.6 & 108.6 & 36.0 & 25.3 & 67.8 & 80.3 & 0.60 & 0.46 \\
\hline 11 & 15 & 21 & 113.9 & 112.4 & 115.6 & 39.3 & 40.0 & 67.3 & 120.9 & 0.41 & 0.44 \\
\hline 12 & 5 & 26 & 107.8 & & 107.8 & 20.2 & 20.2 & 87.6 & 87.6 & 0.56 & \\
\hline 13 & 5 & 24 & 84.5 & & 84.5 & 24.2 & 24.2 & 58.1 & 58.1 & 0.64 & \\
\hline 14 & 5 & 23 & 97.0 & & 97.0 & 17.7 & 17.7 & 43.0 & 43.0 & 0.60 & \\
\hline 15 & 5 & 26 & 89.2 & & 89.2 & 32.0 & 32.0 & 41.4 & 41.4 & 0.57 & \\
\hline 16 & 8 & 26 & 113.2 & & 99.5 & 7.7 & 9.7 & 90.2 & 68.1 & 0.67 & \\
\hline 17 & 8 & 23 & 91.9 & & 91.4 & 8.7 & 13.4 & 69.4 & 67.1 & 0.70 & \\
\hline 18 & 8 & 24 & 86.8 & & 98.4 & 11.9 & 16.9 & 45.7 & 50.2 & 0.66 & \\
\hline
\end{tabular}

circumvent this problem we devised a relative species richness index, the ratio between mean species richness observed each year in a community and the total number of species recorded during the study. As it is similar to Whittaker's coefficient of beta diversity which is the total species richness divided by the mean species richness minus one (MAGURRAN,1988), our relative species richness index is also the inverse of a species turnover index. To cancel the possible effect of time span, the relationship between relative species richness index and MCV was assessed using the same study time span for the localities compared : five years (all localities) or 10 years (11 localities). Relative species index and MCV were computed accordingly.

\section{RESULTS}

Computed MCV, CVA and CVS are presented in table II. Table II shows that in 11 localities values for MCV were higher when computed for the complete series (using all available years) than for the reduced series (5 years). According to a one-tailed paired signed rank test the observed value (11) is significantly $(p=0.029)$ higher than the expected one (7). For CVA and CVS, complete values are higher than reduced values in 12 localities $(p=0.007)$. Consequently, the null hypothesis (community variability through time is unaffected by the study time span) can be rejected and the alternative hypothesis (community variability through time increases with the study time span) is accepted.

When computed with a time span of 5 years, a negative and statistically significant relationship between $\mathrm{MCV}$ and the relative species richness was observed $(R=-0.539, p=0.010$, one-tailed, $n=18$, from data in table II). This is not so, when a study time of 10 years is used $(r=-0.329, p=0.162$, one-tailed, $n=11$, from data in table (I). When only the localities from the river Rhône are included in the analysis, the relationship is significant for both 5 and 10 years $(r=-0.695, p=0.009$, one tailed, $n=11 ; r=-0.913, p=0.002$, one-tailed, $n=7$; respectively, from data in table II). 


\section{DISCUSSION}

In our study three indices of community variability (MCV, CVA, CVS) increased as we increased the number of years included in their calculation. PIMM (1991) found a similar result at population level for birds and insects. The data published by GROSSMAN et al. (1990) does not allow the use of a paired rank test which would enable a comparison with our results. We tested the hypothesis that MCV increases with study time span in their data set by using a regression analysis. This analysis showed that MCV and study time span were positively correlated in their 10 midwestern river assemblages ( $r=0.555, p<0.05$, one tailed test). These findings suggest that the populations studied by these authors and those studied by ourselves do not fluctuate with constant amplitude around a constant equilibrium point. If year-to-year changes in fish population size are driven by environmental variation, an explanation may reside in the reddened spectra of most environmental variables (PIMM, 1991). Another explanation for such a pattern may be that most of the species studied display systematic trends in population size (increasing or decreasing) during the period investigated (PIMM, 1991). To be more confident with the results of this preliminary study, the next step will be to link community variability to environmental factors known to affect variation in population size in stream fishes, such as hydrological variability (BAYLEY \& LI, 1992) or position along the river size gradient (OBERDORFF \& PORCHER, 1992). Whatever the underlying processes, our results lead to the conclusion that, on the basis of species abundance (MCV), species richness (CVS) and total abundance (CVA), it is difficult to postulate that fish communities in the rivers studied remain stable through time. It must be noted that such results are unexpected if the year-to-year changes observed in time series were due only to sampling error, as there is no reason to assume that sampling error increases through time.

According to the "extermination hypothesis" (HORWITZ, 1978) the more that populations fluctuate through time, the more frequent are extinctions with in the community, either balanced or not by immigration of new individuals; this results in a high species turnover (low species richness relative to the colonist pool size). This scenario is concordant with the view that river fish communities at the local scale are open communities and dependant on factors operating on a larger spatial scale such as species pool size and distance from a colonization source (DETENBECK et al., 1992 ; OSBORNE \& WILEY, 1992 ; HUGUENY \& PAUGY, 1995). Within the river Rhône, our results (a negative relationship between relative species richness index and $\mathrm{MCV}$ ) would seem to agree with this hypothesis, but they are equivocal if other rivers are included in the analysis. This discrepancy may result from the effect of merged factors when rivers having different hydrological features and different fauna are included in the same analysis. Unfortunately, we do not have enough data to test the "extermination hypothesis" in each river separately, with the exception of the river Rhône. If our results are not a sampling artifact due to species present in low numbers that are not sampled (pseudo-extinctions), they suggest that extinction and colonization at local scales are important processes in shaping fish communities in the river Rhône and that environmental factors leading to high temporal variability in populations size are key components in explaining species richness of local fish communities in this river. However, no clear relationship was found between species richness at the local scale and temporal variability of physico-chemical and hydrological variables in fish communities within the river Rhône (PERSAT et al., 1994). Obviously, as emphasized by PERSAT et al. (1994), more studies are needed, mainly to define the optimal spatial scale at which the temporal variability of open communities such as those encountered in our study should be considered.

Within the classification scheme proposed by GROSSMAN et al. (1990), our communities are considered highly fluctuating ( $\mathrm{MCV}>75)$. These values are comparable to those reported by GROSSMAN et al. (1990) for 10 midwestern streams of the USA (MCV ranging from 70 to 135). Despite a variety of sampling techniques used and habitats surveyed, highly fluctuating populations appear to be the norm rather than the exception in river fish communities. Unfortunately, it is not possible with our data to compare the effects of sampling method (gill nets vs electrofishing), climate (temperate vs tropical) and anthropogenic stress because they are in a large extent confounded. 
Compared with CV values reported for temperate birds (PIMM, 1991, figure 5.2), ranging from 10 to 70 , riverine fish populations are more variable through time, much more like organisms known to have highly fluctuating populations, such as insects or small mammals, in which CV of population size is frequently above 50 (PIMM, 1991, figures 4.4 and 4.5). Low variability $(C V<50)$ in population size has been reported for some salmonid populations in the UK and the USA (BAYLEY \& LI, 1992). In the river Scorff, a small Brittany stream, salmonid and associated species also displayed relatively limited year-toyear changes in density (CV ca. 60, unpublished results). BAYLEY \& LI (1992) were able to link this low variability to small interannual changes in discharge in the localities surveyed, and this probably also holds for Brittany streams.

Results presented here may have great implications in monitoring freshwater fish communities because it appears unlikely that a reference community can be defined for one place through time, at least in terms of its species abundance. This point has also been emphasized by GROSSMAN et al. (1990). Our study suggests also that insight into understanding riverine fish community dynamics will be provided by broadening the spatial scale of investigation. This broadening should help to identify regional factors affecting species abundances and localized sources of colonization.

\section{ACKNOWLEDGEMENTS}

The authors are grateful for the comments of two anonymous referees which helped to improve the paper. This research was supported by the Environment Programme of CNRS.

\section{REFERENCES}

BAYLEY P.B., LI H.W., 1992. Riverine fishes. In CALOW P., PETTS G.E., The rivers handbook : hydrological and ecological principles, 251-281, Blackwell scientific publications, Oxford.

DETENBECK N.E., DEVORE P.W., NIEMI G.J., LIMA A., 1992. Recovery of temperatestream fish communities from disturbance : a review of case studies and synthesis of theory. Environmental Management, 16, 33-53.

FRUGET J.F., 1992. Ecology of the lower Rhône after 200 years of human influence : a review. Regulated rivers : research \& management, 7, 233-246.

GROSSMAN G.D., MOYLE P.B., WHITTAKER J.O. JR, 1982. Stochasticity in structural and functional characteristics of an Indiana stream fish assemblage : a test of community theory. Am. Nat., 120, 423-453.

GROSSMAN G. D, DOWD J. F., CRAWFORD M., 1990. Assemblage stability in stream fishes : a review. Environmental Management, 14, 661-671.

HORWITZ R. J., 1978. Temporal variability patterns and the distributional patterns of stream fishes. Ecol. Monogr., 48, 307-321.

HUGUENY B., PAUGY D. 1995. Unsaturated fish communities in African rivers. Am. Nat., 146, 162-169.

LÉVÊQUE C., FAIRHURST C.P., ABBAN K., PAUGY D., CURTIS M.S., TRAORÉ K., 1988. Onchocerciasis control programe in west Africa : ten years monitoring of fish populations. Chemosphere, 17, 421-440.

MAGURRAN A.E., 1988. Ecological diversity and its measurement. Princeton University Press, Princeton. $179 \mathrm{p}$.

OBERDORFF T., PORCHER J.P., 1992. Fish assemblage structure in Brittany streams (France). Aquat. Living Resourc., 5, 215-223.

OSBORNE L.L., WILEY M.J., 1992. Influence of tributary spatial position on the structure of warmwater fish communities. Can. J. Fish. Aquat. Sci., 49, 671-681. 
PERSAT H., COPP G.H., 1990. Electric fishing and point abundance sampling for the ichthyology of large rivers. In COWX I.G., Developments in Electric Fishing, 197-209, Blackwell Scientific Publications, Oxford.

PERSAT H., OLIVIER J.M., PONT D., 1994. Theoretical habitat templets, species traits, and species richness : fish in the Upper Rhône River and its floodplain. Freshwater Biology, 31, 439-454.

PIMM S.L., 1991. The balance of nature ? The University of Chicago Press, Chicago \& London, $434 \mathrm{p}$.

SCHOENER T.W., 1987. Axes of controversy in community ecology. In MATTHEWS W.J., HEINS D.C., Community and evolutionary ecology of North American stream fishes, 8-16, University of Oklahoma Press. 